\title{
Effect of Phosphate Solubilizing Bacteria on the Uptake of Heavy Metals by Corn Plants in a Long-Term Sewage Wastewater Treated Soil
}

\author{
Hashem Mahmoud Mohamed and Yaser Ayesh Almaroai
}

\begin{abstract}
Three phosphate solubilizing bacteria (PSB) were isolated from contaminated soil and putatively identified as Bacillus sp., Azotobacter sp. and Pseudomonas sp. The maximum amount of $P$ solubilized $(3.11 \mathrm{mg} / \mathrm{ml})$ was recorded for Bacillus sp. which also recorded the highest phosphate solubilization index (2.72). Bacterial isolates produced a substantial amount of IAA both in the absence and presence of heavy metals concentrations. A greenhouse pot experiment was conducted to study the effect of isolated (PSB) on the uptake of heavy metals by corn grown on a contaminated soil. The results showed that inoculation of corn plants with PSB isolates caused significantly $(p=0.05)$ decreases in the uptake of heavy metals by corn plants. The percent decreases in heavy metals uptake induced by Bacillus sp. were $69 \%, 70.5 \%, 80.7 \%$ and $62.9 \%$ for $\mathrm{Zn}, \mathrm{Cu}, \mathrm{Pb}$ and $\mathrm{Cd}$ respectively, compared with control. These results suggested that the PSB inoculant due to its intrinsic abilities of growth promotion and increase the solubility of $P$ in soil could be exploited for phytostabilization of heavy metals contaminated site.
\end{abstract}

Index Terms-Phytostabilization, phosphate solubilizing bacteria, Bacillus sp., inoculation, heavy metals.

\section{INTRODUCTION}

Heavy metals pollution of soil is a significant environmental problem, elevated levels of heavy metals not only decrease soil microbial activity and crop production, but also threaten human health through the food chain [1]. The main options for reclamation of soil or sediments polluted by metals are insitu and exsitu techniques. The insitu remediation of soil aims at increasing the stabilization of metals either on soil particles, or by other methods such as plants, so the potential mobility or bioavailability of the toxic metals to environment are lowered (e,g immobilization). On the other hand, exsitu techniques aim at extracting or separating metals from soil through a series of chemical, physical, or biological methods in a specially designed reactor [2].

The remediation of metal-contaminated soils by traditional physicochemical methods is both very costly and destructive to the normal properties of the soil [3]. Therefore, biotechnological approaches have received a great deal of attention in recent years. Phytoremediation, the use of plant for metal reclamation, includes phytoextraction,

Manuscript received August 28, 2016; revised December 20, 2016.

Hashem Mahmoud Mohamedis with the Department of Soils and Water, Faculty of Agriculture, University of Assiut, Assiut, Egypt (e-mail: hashembefoul@yahoo.com).

Yaser Ayesh Almaroai is with the Department of Biology, College of Science, Umm Al-Qura University, Makkah 673, Saudi Arabia (e-mail: Yaseragr2007@yahoo.com). rhizofiltration, phytostabilization and phytovolatilization [4]-[6]. Particularly, phytostabilization (immobilization and reduction in the mobility and bioavailability of contaminants by plant root and their associated microbes), is currently receiving a great deal of attention [7]. Many different chemical and biological amendments (e.g., limestone, calcinit, urea, calcium carbonate and cow slurry) have been used to increase the plant growth and/or reduce the metal solubility and bioavailability in contaminated soils [7]-[9]. Even though some chemical amendments decrease the metal uptake in plants, these amendments (e.g., cyclonic ashes, steel shots, $\mathrm{CaO})$ are toxic to plants and their associated beneficial soil microbes [10], [11].

In recent years, metal resistant microbes have been employed because they display a high potential to alter the metal mobility and bioavailability. Phosphate fertilizers can also be used to immobilize heavy metals in soil [12]-[14]. Insoluble phosphate compounds can be solubilized by organic acids and phosphatase enzymes produced by microorganisms [15], [16]. For example, phosphate solubilizing bacteria (PSB) have been shown to enhance the solubilization of insoluble $\mathrm{P}$ compounds through the release of low molecular weight organic acids [17]. The objectives of this study were to isolate PSB from contaminated soils, characterize PSB in relation to $\mathrm{P}$ solubilization, and examine their effects on the plant growth and uptake of some heavy metals ( $\mathrm{Zn}, \mathrm{Cu}, \mathrm{Pb}$, and $\mathrm{Cd}$ ) within corn (zea maize) plant grown on contaminated soil.

\section{MATERIALS AND METHODS}

\section{A. Isolation and Characterization of PSB}

Soil samples were collected from Arab Elmadabegh, Assiut, Egypt where the soils have been irrigated with sewage waste water for more than 40 years. For isolation of phosphate solubilizing bacteria, $1 \mathrm{~g}$ soil was suspended in $100 \mathrm{ml}$ of distilled water. An aliquot $(0.1 \mathrm{ml})$ from decimal dilutions was inoculated on Picovskaya's agar medium (Glucose, $10 \mathrm{~g}$; $\mathrm{Ca}_{3}\left(\mathrm{PO}_{4}\right)_{2}, 5 \mathrm{~g} ;\left(\mathrm{NH}_{4}\right)_{2} \mathrm{SO}_{4}, 0.5 \mathrm{~g} ; \mathrm{KCl}, 0.2 \mathrm{~g} ; \mathrm{MgSO}_{4} .7 \mathrm{H}_{2} \mathrm{O}$, $0.1 \mathrm{~g} ; \mathrm{MnSO}_{4}$ trace; $\mathrm{FeSO}_{4}$ trace ; $\mathrm{pH} 7$ ). After incubation for 5 days at $28^{\circ} \mathrm{C}$, colonies indicating halo zones with a large relative diameter were picked and purified on Picovskaya's agar medium for studying their characterizations. The isolated bacteria were identified by morphological characteristics in which gram staining, shapes, IMVIC test and motility. Also, the following physiological characteristics were tested: starch hydrolysis, gelatin hydrolysis, production of catalase enzyme, nitrate reduction, fermentation of sucrose, lactose and 
mannitol.

\section{B. Determination of Solubilization Index}

The ability of the selected isolates to solubilize insoluble phosphate was described by the solubilization index: the ratio of the total diameter (colony + halo zone) and the colony diameter [18]. All the suspected colonies were screened for phosphate solubilization on Picovskaya's agar medium. Halo zone formation around bacterial colonies was measured after inoculated for five days at $28^{\circ} \mathrm{C}$.

\section{Determination of Soluble P by Selected Isolates}

The ability of the selected isolates to solubilize insoluble tricalcium phosphate was measured in $100 \mathrm{ml}$ aliquots of Pikovskaya's liquid medium. The isolates were grown in 100 $\mathrm{ml}$ aliquots of the liquid medium for 5 days at $28^{\circ} \mathrm{C}$, and then the cultures were filtered and centrifuged at 10000 r.p.m. for 10 minutes. Soluble phosphorus in the supernatant and blank sample of the medium was determined using colorimetrically at $660 \mathrm{~nm}$ with standard $\mathrm{KH}_{2} \mathrm{PO}_{4}$.

\section{Extraction and Determination of Auxins Produced by Bacterial Isolates}

Extraction of auxins produced in bacterial cultures was performed as follows, according to the method described by Strzelczyk and Pokojska-Burdziej [19]. Each of the strains was grown for $120 \mathrm{~h}$ in Pikovskaya's liquid medium with L-tryptophan (200 $\mathrm{mg} / \mathrm{l})$ in the presence and absence of heave metal concentration [20]. Aliquot of $100 \mathrm{ml}$ of the culture filtrate, was centrifuged at 1000 r.p.m. for 30 minutes and supernatant was acidified to $\mathrm{pH} 3$ with $1 \mathrm{~N} \mathrm{HCl}$ then extracted twice with $100 \mathrm{ml}$ of peroxide free ethyl ether in a separatory funnel. The ether extract was then evaporated at $40-45^{\circ} \mathrm{C}$ to dryness and the residue was dissolved in $2 \mathrm{ml}$ methanol and used for determination of auxins.

Indole acetic acid (IAA) was determinated by colorimetric Salkowski reaction [21], as follows: two $\mathrm{ml}$ of the prepared methanolic solution (equivalent to $100 \mathrm{ml}$ of the culture) was added to $4 \mathrm{ml}$ of Salkowski reagent $\left(2.025 \mathrm{~g} \mathrm{FeCl}_{3}+300 \mathrm{ml}\right.$ $\mathrm{H}_{2} \mathrm{SO}_{4}+500 \mathrm{ml} \mathrm{H} \mathrm{H}_{2} \mathrm{O}$ ). The mixture was kept in darkness for 15-30 min. before colorimetric reading of the developed rosy color on a Spectronic 20, Baush \& Lomb at $530 \mathrm{~nm}$. A standard curve of authentic IAA was performed; consisted of solutions of different concentrations of a pure IAA ranged from 1-10 ppm that were treated with Salkowski reagent as previously described and measured colorimetrically at 530 $\mathrm{nm}$.

\section{E. Influence of Bacterial Strains on Growth and Heavy Metals Uptake}

A greenhouse pot experiment was conducted to study the effect of isolated phosphate solubilizing bacteria on the uptake of heavy metals by corn (zea maize) grown on a contaminated soil. The physical and chemical properties of soil are presented in Table I. Plastic pots, each one has $15 \mathrm{~cm}$ in diameter and $20 \mathrm{~cm}$ in depth were filled with $4 \mathrm{~kg}$ of studied soil samples. Four grains of corn cv. single hybrid-10 were planted in each pot and the plants were thinned to two plants per pot after germination. In this experiment, four inoculation treatments were done: non-inoculated plant used as control, plants inoculated with Bacillus sp., plants inoculated with
Pseudomonas sp. and plants inoculated with Azotobacter sp. Soil moisture was maintained to near the field water capacity until the end of the experiment.

TABLE I: SOME PHYSICAL AND CHEMICAL CHARACTERISTICS OF SOIL USED

\begin{tabular}{l|c|c}
\hline Properties & units & Values \\
\hline Sand & $\left(\mathrm{g} \mathrm{kg}^{-1}\right)$ & 601 \\
\hline Silt & $\left(\mathrm{g} \mathrm{kg}^{-1}\right)$ & 310 \\
\hline Clay & $\left(\mathrm{g} \mathrm{kg}^{-1}\right)$ & 89 \\
\hline Texture & & Sandy loam \\
\hline $\mathrm{pH}(1: 1)$ & & 7.18 \\
\hline $\mathrm{EC}(1: 1)$ & $\left(\mathrm{ds} \mathrm{m}^{-1}\right)$ & 1.24 \\
\hline $\mathrm{CaCO}_{3}$ & $\left(\mathrm{~g} \mathrm{~kg}^{-1}\right)$ & 4.56 \\
\hline OM & $(\%)$ & 2.50 \\
\hline Total N & $(\%)$ & 0.62 \\
\hline Available P & $\left(\mathrm{mg} \mathrm{kg}^{-1}\right)$ & 12.45 \\
\hline DTPA-extractable $\mathrm{Zn}$ & $\left(\mathrm{mg} \mathrm{kg}^{-1}\right)$ & 6.22 \\
\hline DTPA-extractable $\mathrm{Cu}$ & $\left(\mathrm{mg} \mathrm{kg}^{-1}\right)$ & 4.49 \\
\hline DTPA-extractable $\mathrm{Pb}$ & $\left(\mathrm{mg} \mathrm{kg}^{-1}\right)$ & 3.05 \\
\hline DTPA-extractable $\mathrm{Cd}$ & $\left(\mathrm{mg} \mathrm{kg}^{-1}\right)$ & 0.10 \\
\hline
\end{tabular}

\section{F. Preparation of Bacterial Inoculants}

Sterilized peat moss was used as a carrier for inoculant preparations. The pulverized dry peat moss, was neutralized to $\mathrm{pH} 7$ with $\mathrm{CaCO}_{3}$ and $\mathrm{Ca}(\mathrm{OH})_{2}$, and distributed in batches of $50 \mathrm{~g}$ each in polyethylene bags and autoclaved for 30 minutes at $121^{\circ} \mathrm{C}$ on three successive days. Bacterial strains were grown on TY (tryptone-yeast extract) medium for 5 days at $28{ }^{\circ} \mathrm{C}$. Aliquots of $25 \mathrm{ml}$ of each bacterial strains broth culture were used per $50 \mathrm{~g}$ of the sterilized carrier material and immediately stored at $4{ }^{\circ} \mathrm{C}$ until use (as much one week of storage at $4{ }^{\circ} \mathrm{C}$ ). The grains of each treatment, in polyethylene bag, were inoculated by adding $10 \mathrm{ml}$ of $40 \%$ gum solution and after mixing, the peat inoculant was added and thoroughly mixed with the grains until uniformly surface coated. The inoculant was added to grains at a rate of $15 \mathrm{~g} / 100 \mathrm{~g}$ grains. Peat inocula contained approximately $10^{9}$ viable cells of Bacillus and Pseudomonas $/ g$ and $10^{8}$ viable cells of Azotobacter/g.

\section{G. Plant Analysis}

Corn plants were harvested after 60 days of sowing. Shoots and roots were separated and then oven-dried at $70{ }^{\circ} \mathrm{C}$ to a constant weight, to determine roots and shoots dry weights. Dried shoots were ground and submitted to the acid-digestion using a 2:1 $\mathrm{HNO}_{3}: \mathrm{HClO}_{4}$ acid mixture. The digests were analyzed for heavy metal $(\mathrm{Zn}, \mathrm{Cu}, \mathrm{Pb}$ and $\mathrm{Cd})$ by atomic absorption spectrophotometer (AAS).

\section{H. Statistical Analysis}

The data reported in this paper were the mean values based on the five replicates. Differences among treatments were tested by ANOVA and mean values among treatments were compared by Duncan's Multiple Range Test at $P=0.05$. Statistical analysis of the data was performed by using the statistical computer program [22].

\section{RESULTS AND DISCUSSION}

\section{A. Isolation and Identification of PSB}

A total of 23 phosphate solubilizing bacterial colonies were isolated on the Picovskaya's agar medium , containing 
insoluble tri-calcium phosphate from heavy metals contaminated soil. Out of 23 bacterial isolates three isolates showed high relative $\mathrm{P}$ solubilization index (PSI) on the Picovskaya's medium. The isolates were further characterized by a series of biochemical reaction and putatively identified as Bacillus sp., Pseudomonas sp. and Azotobacter sp. The morphological and biochemical characteristics of these isolates were shown in the Table II. These bacterial genera have been reported to include PSB by others. For example, Roane [23] isolated $\mathrm{Pb}$ resistant bacteria (Pseudomonas marginalis and Bacillus megaterium) from heavy metal contaminated soils. Karpagam and Nagalakshmi [24] also isolated bacteria from agriculture soils and reported the genera Bacillus, Pseudomonas and Azotobacter as PSB.

TABLE II: MORPHOLOGICAL AND BIOCHEMICAL CHARACTERISTICS OF ISOLATED PHOSPHATE SOLUBILIZING BACTERIA

\begin{tabular}{l|c|c|c}
\multicolumn{4}{c}{ ISOLATED PHOSPHATE SOLUBILIZING BACTERIA } \\
\hline Characteristics & Bacillus sp. & Pseudomonas sp. & Azotobacter $\mathrm{sp}$ \\
\hline Gram reaction & G+ve & G-ve & G-ve \\
\hline Shape & Rods & Rods & Rods \\
\hline Motility & + & + & + \\
\hline Pigments & - & + & + - \\
\hline $\mathrm{H}_{2}$ S production & - & + & + \\
\hline Indole & - & - & + \\
\hline Methyl red & - & - & + \\
\hline Vogues Proskauer & + & - & + \\
\hline Citrate utilization & + & + & + \\
\hline Nitrate reduction & + & + & + \\
\hline Starch hydrolysis & + & + & - \\
\hline Gelatin hydrolysis & + & - & + \\
\hline Lactose fermentation & + & - & + \\
\hline Sucrose fermentation & + & + & + \\
\hline Fructose fermentation & + & - & + \\
\hline Mannitol fermentation & + & - & \\
\hline
\end{tabular}

\section{B. Phosphate Solubilization}

Characterization of PSB with respect to $\mathrm{P}$ solubilization index (PSI) and solubilized $\mathrm{P}$ are presented in Table III. The PSB ability in dissolving inorganic $\mathrm{P}$ (tricalcium phosphate) in Picovskaya's agar medium was qua ntitatively estimated with the phosphate solubilizing index. In the present study, the index created by the three identified PSB strains were different, implying differential ability for $\mathrm{P}$ solubilization. The largest index was noted for Bacillus sp., followed by Azotobacter sp., and Pseudomonas sp. The strains were further studied for ability to solubilize phosphorus from insoluble phosphate in Pikovskaya,s liquid medium containing tricalcium phosphate. Amounts of phosphorus solubilized from tricalcium phosphate by the bacterial strains are shown in Table III. The maximum amount of $\mathrm{P}$ solubilized (3.11 mg ml) was recorded for Bacillus sp which also recorded the highest phosphate solubilization index, 2.72 (Table II). The results also show that the lowest amount of $\mathrm{P}$ solubilized was recorded by Pseudomonas sp (1.62 mg / ml).

\section{Production of IAA by Isolated PSB}

Promoting rhizobacteria is the production of IAA, which may directly affect the growth of plants. It is known that the IAA released by promoting rhizobacteria enhances root growth directly by stimulating elongation of the plant cell or affecting cell division [25], [26]. In the present investigation, bacterial isolates produced a substantial amount of IAA after $120 \mathrm{~h}$ of incubation both in the absence and presence of heavy metals concentrations (Fig. 1). But, IAA production was decrease in the presence of heavy metals in the culture. The results also show that the strain Pseudomonas sp. produce the highest amounts of IAA ( 8.03 and $7.43 \mathrm{mg} / \mathrm{l})$ in the absence or presence of heavy metals, respectively, while, the lowest amounts (6.33 and $5.69 \mathrm{mg} / \mathrm{l})$ produced by the strain Azotobacter sp. Similar evidence of IAA production by Bacillus weihenstephanensis [27], and Bacillus sp. [28] under heavy metals stress is reported. In other study, Pseudomonas fluorescens and Mycobacterium sp. has also been reported to produce IAA and promote the growth of Brassica napus under Cd stress [29].

TABLE III: Phosphate Solubilization Assay by Isolated Phosphate SOLUBILIZING BACTERIA

\begin{tabular}{l|c|c}
\hline \multicolumn{1}{c|}{ Strain } & $\begin{array}{c}\text { Solubilizing } \\
\text { index }\end{array}$ & $\begin{array}{c}\text { Solubilized } \mathrm{p} \text { in } \\
\text { liquid culture } \\
\mu \mathrm{g} \mathrm{ml}^{-1}\end{array}$ \\
\hline Liquid medium & - & $0.009 \pm 0.09$ \\
\hline Bacillus sp. & $2.72 \pm 0.02$ & $3.11 \pm 0.03$ \\
\hline Pseudomonas $\mathrm{sp}$. & $1.62 \pm 0.04$ & $1.54 \pm 0.05$ \\
\hline Azotobacter $\mathrm{sp}$ & $2.11 \pm 0.06$ & $0.65 \pm 0.07$ \\
\hline
\end{tabular}

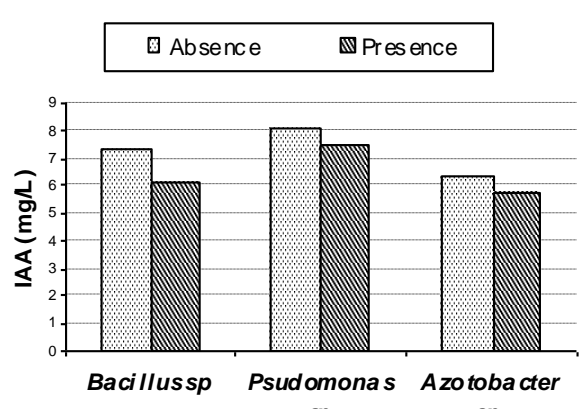

sp.

Fig. 1. IAA production by isolated phosphate solubilizing bacteria in the absence or presence of heavy metals.

\section{Influence of PSB Isolates on Plant Growth}

Corn plant was chosen for this study based on their high biomass, fast growth rates and ability to remove heavy metals from contaminated soils [30]. This plant appeared to be health in these soils that are irrigated by untreated sewage water. Inoculation with any of three tested PSB isolates (Bacillus sp., Pseudomonas sp. and Azotobacter sp) caused significant ( $P$ $=0.05$ ) increases in dry weight of roots and shoots of corn plants Compared with the control soil (Fig. 2). Inoculation with Azotobacter sp. was the most stimulation in roots and shoots dry weight compared with other bacterial strains. This enhancement of root and shoot dry weights imposed by Azotobacter sp. may due to $\mathrm{N}_{2}$-fixation. The percent increases in root and shoot dry weights induced by Azotobacter sp. respectively were $67.7 \%$ and $64.8 \%$ compared with uninoculated control. This promotive effect could be attributed to the potential of PSB to increase the availability of nutrients, such as phosphorus and phytohormone production [31]. Additionally, PSB protect plant from phytopathogens through the production of antibiotics, $\mathrm{HCN}$, phenazines and anti-fungal metabolites [32], [33]. Inoculation of plants with PSB generally results in improved plant growth and yield in particular, under glasshouse condition [34]. More importantly, investigations conducted under field level using wheat and maize plants have revealed that PSB could 
drastically increase plant growth and yield, also reduce the usage of chemical or organic fertilizer [35].

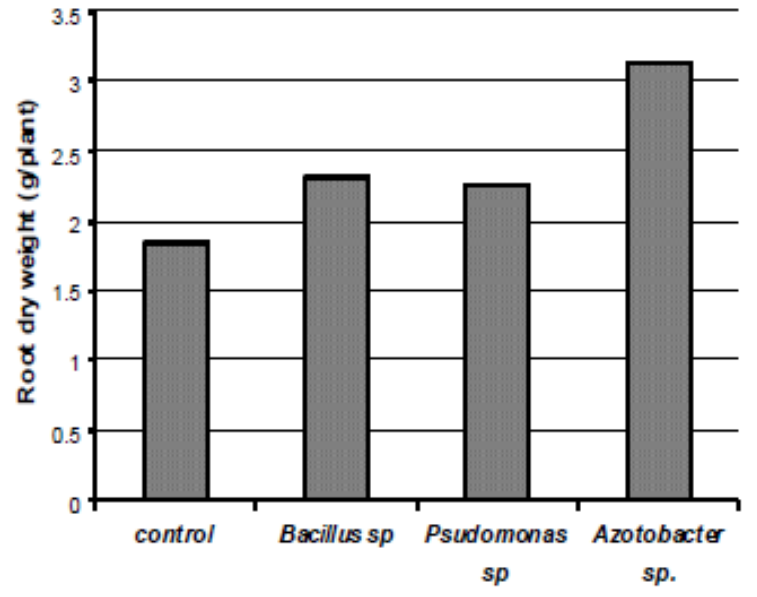

(A)

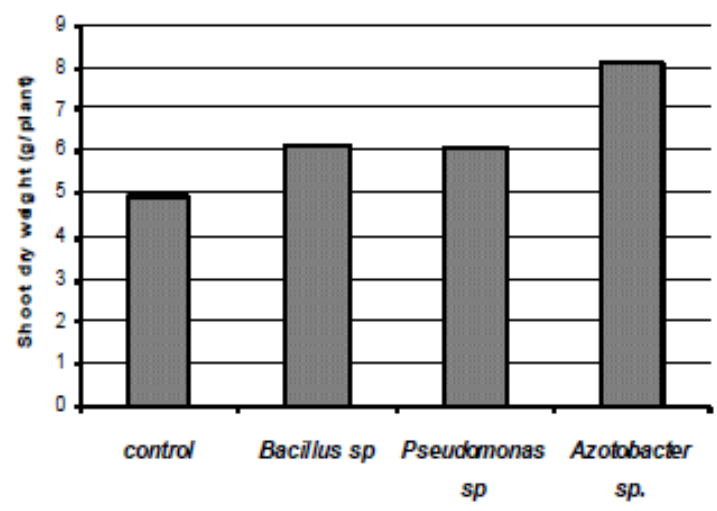

(B)

Fig. 2. Treatments effect on; root (A) and shoot (B) dry weights of corn plant.

\section{E. Influence of PSB Isolates on Heavy Metals Uptake}

Since the plant associated microbes play pivotal roles in altering metal mobility/solubility in the rhizosphere and in enhancing the overall phytoremediation potential of plant, the effect of inoculation with PSB on the uptake of heavy metals was assessed. The results showed that inoculation of corn plants with PSB isolates (Bacillus sp., Pseudomonas sp. and Azotobacter $\mathrm{sp})$ caused significantly $(P=0.05)$ decreases in the uptake of $\mathrm{Zn}, \mathrm{Cu}, \mathrm{Pb}$ and $\mathrm{Cd}$ for corn plants (Fig. 3). Bacterial strain Bacillus sp. was the most effective in decrease heavy metals uptake by corn plants compared with other strains (Pseudomonas sp. and Azotobacter sp.). The percent decreases in heavy metals uptake induced by Bacillus sp. were $69 \%, 70.5 \%, 80.7 \%$ and $62.9 \%$ for $\mathrm{Zn}, \mathrm{Cu}, \mathrm{Pb}$ and $\mathrm{Cd}$ respectively, compared with uninoculated control. The use of metal resistant bacteria, which are present in the rhizosphere soils, have received much concern as they can affect heavy metal mobility and its uptake by plants through various reactions such as, oxidation/reduction, metal biosorption and heavy metal-ligand complexation [36]-[39].

In agreement with our data, metal resistant bacteria such as, Pseudomonas sp., Pantoea sp. and Enterobacter sp., were also found to have plant growth promoting characters including IAA production and $\mathrm{P}$ solubilization that can improve plant growth and reduce metal stress symptoms in plants [40], [41]. Various mechanisms have been proposed for the phosphate-induced immobilization of metals, which include direct metal adsorption by $\mathrm{P}$ compounds, phosphate anion-induced metal adsorption, direct precipitation of metals with $\mathrm{P}$ in solution as metal phosphates, precipitation through the liming action of rock phosphate, and rhizosphere modification through acidification [42]. Previously, experiments with various plants revealed that the inoculation with Bacillus megatherium SR28C reduced translocation of $\mathrm{Ni}$ from roots to shoots compared with the control. This effect was attributed to the increased metal biosorption by Bacillus megatherium SR28C [43].

\section{CONCLUSION}

The most effective $\mathrm{P}$ solubilizing strains isolated from contaminated soils were putatively identified as Bacillus sp., Pseudomonas sp. and Azotobacter sp. Results indicated that inoculation with isolated PSB were highly effective in enhancement plant growth and reducing uptake of $\mathrm{Zn}, \mathrm{Cu}, \mathrm{Pb}$ and $\mathrm{Cd}$ by corn plants. Bacterial strain Bacillus sp. was the most effective in decrease heavy metals uptake by corn plants compared with other strains (Pseudomonas sp. and Azotobacter sp.). This strain recorded the largest phosphate solubilization index and the maximum amount of $\mathrm{P}$ solubilized (2.42 $\mathrm{mg} \mathrm{ml}$ ) in Pikovskaya,s liquid medium containing tricalcium phosphate. So, the inoculation of PSB in contaminated soil decrease heavy metal uptake by solubilization of $\mathrm{P}$ and subsequent formation of insoluble precipitation of metals with $\mathrm{P}$ in solution as metal phosphates. As a result, successful inoculation of this strain (Bacillus sp.) may be useful for heavy metals phytostabilization and for possible control of heavy metals entry into food chain. Future studies should be focused on the beneficial effects of this strain on heavy metals phytostabilization under long term field condition.
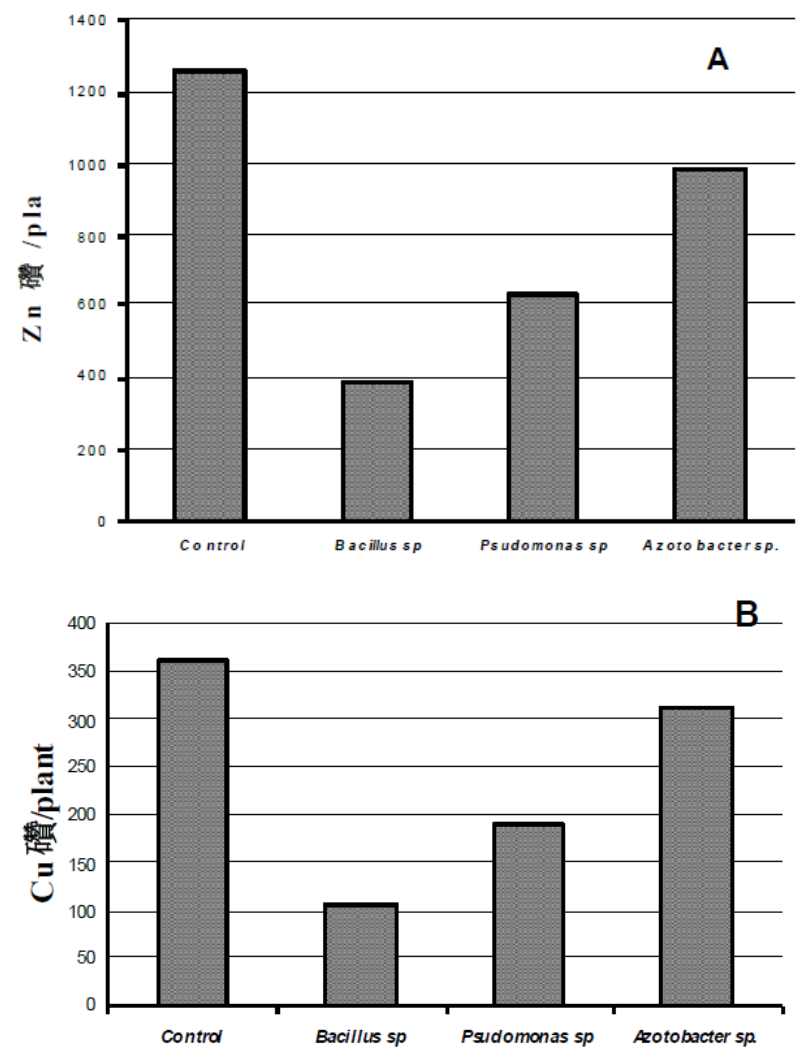

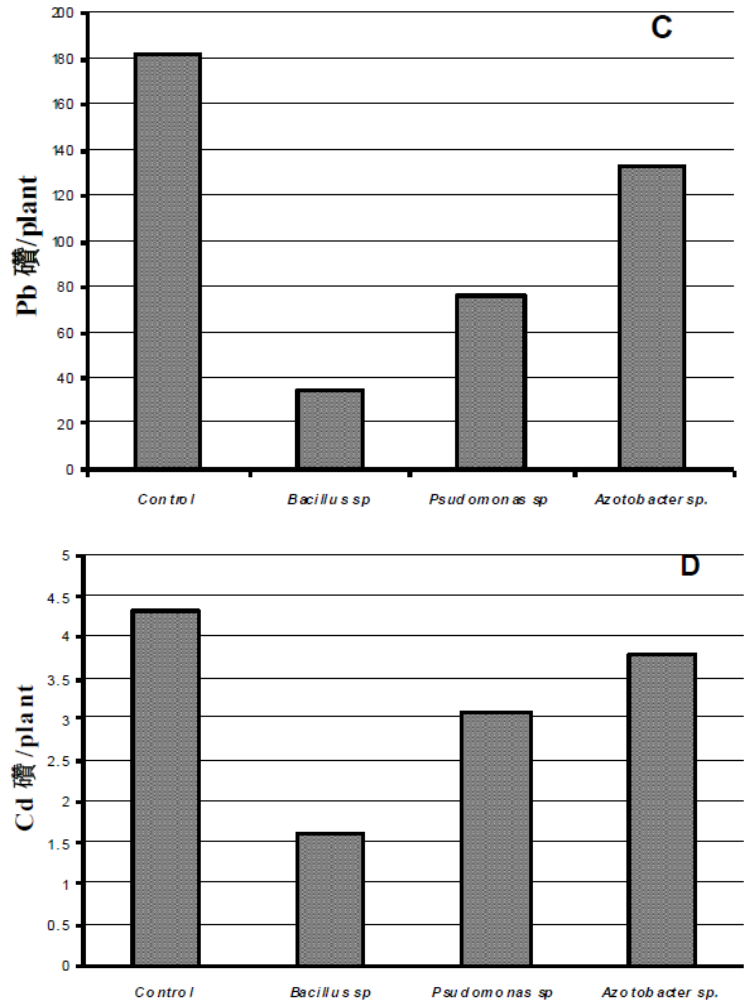

Fig. 3. Treatments effect on the uptake of; $\mathrm{Zn}(\mathrm{A}), \mathrm{Cu},(\mathrm{B}), \mathrm{Pb}(\mathrm{C})$ and $\mathrm{Cd}(\mathrm{D})$ by shoot of corn plants.

\section{ACKNOWLEDGMENT}

The authors would like to thank Faculty of Agriculture, Assiut University, Egypt and College of Sciences, Umm AlQura University, Kingdom of Saudi Arabia for supporting his study.

\section{REFERENCES}

[1] M. McLaughlin and B. Singh, "Cadmium in soil and plants: A global perspective," Cadmium in Soils and Plants, The Netherlands: Kluwer Academic Publishing, 1999, ch. 1, pp. 13-21.

[2] J. Peng, S. Yong-hui, Y. Peng et al., "The remediation of heavy metals contaminated sediment," Journal of Hazardous Materials, vol. 161, pp. 633-640, 2009.

[3] S. Tandy, R. Schulin, and B. Nowack, "The influence of EDDS on the uptake of heavy metals in hydroponically grown sunflowers," Chemosphere, vol. 62, pp. 1454-1463, 2006.

[4] M. L. Mitch, "Phytoextraction of toxic metals: A review of biological mechanisms," Journal of Environmental Quality, vol. 31, pp. 109-120, 2002.

[5] M. Ghosh and S. Singh, "A review on phytoremediation of heavy metals and utilization of its byproducts," Applied Ecology and Environmental Research, vol. 3, no.1 pp. 1-18.

[6] E. Pilon-Smits, "Phytoremediation," Annu Rev Plant Biol., vol. 56 pp. $15-39,2005$

[7] Q. Wu, S. Wang, P. Thangavel et al., "Phytostabilization potential of Jatropha curcas L. in polymetallic acid mine tailings," International Journal of Phytoremediation, vol. 13, pp. 788-804, 2011.

[8] L. Epelde, J. Becerril, I. Mijangos, and C. Garbisu, "Evaluation of the efficiency of a phytostabilization process with biological indicators of soil health," Journal of Environmental Quality, vol. 38, pp. 2041-2049, 2009.

[9] K. Li and W. Ramakrishna, "Effect of multiple metal resistant bacteria from contaminated lake sediments on metal accumulation and plant growth," Journal of Hazardous Materials, vol. 189, pp. 531-539, 2011.

[10] G. Mühlbachová and P. Tlustos, . "Effects of liming on the microbial biomass and its activities in soils long-term contaminated by toxic elements," Plant, Soil and Environment, vol. 52, pp. 345-352, 2006.

[11] A. Ruttens, M. Mench, J. Colpaert et al., "Phytostabilization of a metal contaminated sandy soil. II: Influence of compost and/or inorganic metal immobilizing soil amendments on phytotoxicity and plant availability of metals," Environmental Pollution, vol. 144, pp. 524-532, 2006.

[12] S. McGowen, N. Basta, and G. Brown, "Use of diammonium phosphate to reduce heavy metal solubility and transport in smelter-contaminated soil," Journal of Environmental Quality, vol. 30, pp. 493-500, 2001

[13] N. Bolan, D. Adriano, and R. Naidu, "Role of phosphorus in immobilization and bioavailability of heavy metals in the soil-plant system," Reviews on Environmental contamination and Toxicology, vol. 177, pp. 1- 44, 2003.

[14] N. Basta and S. McGowen, "Evaluation of chemical immobilization treatments for reducing heavy metal transport in a smelter-contaminated soil," Environmental Pollution, vol. 127, pp. 73-82, 2004.

[15] R. Kucey, "Phosphate-solubilizing bacteria and fungi in various cultivated and virgin Alberta soils," Canadian Journal of Soil Science, vol. 63, pp. 671-678, 1983.

[16] R. Duponnois, A. Colombet, V. Hien, and J. Thioulouse, "The mycorrhizal fungus Glomus intraradices and rock phosphate amendment influence plant growth and microbial activity in the rhizosphere of Acacia holosericea," Soil Biology \& Biochemistry, vol. 37, pp. 1460-1468, 2005.

[17] S. Sahu and B. Jana, "Enhancement of the fertilizer value of rock phosphate engineered through phosphate-solubilizing bacteria," Ecological Engineering, vol. 15, pp. 27-39, 2000.

[18] M. E. Premono, A. Moawad, and P. Velk, "Effect of phosphate-solubilizing Pseudomonas putida on the growth of maize and its survival in the rhizosphere," Indonesian Journal of Crop Science, vol. 11, pp. 13- 23, 1996.

[19] E. Strzelczyk and A. Pokojska-Burdziej, "Production of auxins and gibberellin-like substances by mycorrhizal fungi, bacteria and actinomycetes isolated from soil and the mycorrhizosphere of pine (Pinus silvestris L.)," Plant and Soil, vol. 81, no.2, pp. 185-194, 1984.

[20] J. Carrasco, P. Armario, E. Pajuelo et al., "Isolation and characterization of symbiotically effective Rhizobium resistant to arsenic and heavy metals after the toxic spill at the Aznalcóllar pyrite mine," Soil Biology \& Biochemistry, vol. 37, pp. 1131-1140, 2005.

[21] Y. Tang and J. Bonner, "The enzymatic inactivation of indole acitic acid .1- Some characteristic of the enzyme contained in pea seedling," Archives of Biochemistry, vol. 13, pp. 11-25, 1947.

[22] StatSoft, "Statistica for windows (computer program manual)," StatSoft, Inc., Tulsa, OK.

[23] T. Roane, "Lead resistance in two bacterial isolates from heavy metal-contaminated soils," Microbial Ecology, vol. 37, pp. 218-224, 1995.

[24] T. Karpagam and P. Nagalakshmi, "Isolation and characterization of phosphate solubilizing microbes from agricultural soil," Int. J. Microbial. App. Sci., vol. 3, no. 3, pp. 601-614, 2014.

[25] M. Malhotra and S. Srivastava, "Stress-responsive indole-3-acetic acid biosynthesis by Azospirillum brasilense SM and its ability to modulate plant growth," European Journal of Soil Biology, vol. 45, pp. 73-80, 2009.

[26] P. Davies, "The plant hormones: Their nature, occurrence and functions," Kluwer Academic Publishers, New York, 2010, p. 656.

[27] M. Rajkumar, Y. Ma, and H. Freitas, "Characterization of metal resistant plant growth promoting Bacillus weihenstephanensis isolated from serpentine soil in Portugal," Journal of Basic Microbiology, vol. 48, pp. 500-508, 2008.

[28] P. Wani, M. Khan, and A. Zaidi, "Chromium reduction, plant growth promoting potentials, and metal solubilization by Bacillus sp. isolated from alluvial soil," Current Microbiology, vol. 54, pp. 37-243, 2007.

[29] E. Dell'Amico, L. Cavalca, and V. Andreoni, "Improvement of Brassica napus growth under cadmium stress by cadmium-resistant rhizobacteria," Soil Biology \& Biochemistry, vol. 40, pp. 74-84, 2008.

[30] R. Abou-Shanab, J. Angle, and R. Chaney, "Bacterial inoculants affecting nickel uptake by Alyssum murale from low, moderate and high Ni soils," Soil Biology \& Biochemistry, vol. 38, pp. 2882-2889, 2006.

[31] E. Viruel, M. Lucca, and F. Siñeriz, "Plant growth promotion traits of phosphobacteria isolated from Puna Argenti," Archives of Microbiology, vol. 193, pp. 489-496, 2011.

[32] A. Upadhayay and S. Srivastava, "Evaluation of multiple plant growth promoting traits of an isolate of Pseudomonas fluorescens strain Psd," Indian Journal of Experimental Biology, vol. 48, pp. 601-609, 2012.

[33] Y. Singh, P. Ramteke, and P. Shukla, "Isolation and characterization of heavy metal resistant Pseudomonas sp. and their plant growth promoting activities," Advances in Applied Science Research, vol. 4, pp. 269-272, 2013. 
promoting activities," Advances in Applied Science Research, vol. 4 , pp. 269-272, 2013.

[34] M. Khan, A. Zaidi, M. Ahemad et al., "Plant growth promotion by phosphate solubilizing fungi-current perspective," Archives of Agronomy and Soil Science, vol. 56, pp. 73-98, 2010.

[35] H. Singh and M. Reddy, "Effect of inoculation with phosphate solubilizing fungus on growth and nutrient uptake of wheat and maize plants fertilized with rock phosphate in alkaline soils," European Journal of Soil Biology, vol. 47, no.1, pp. 30-34, 2011.

[36] [36] Y. Ma, M. Prasad, M. Rajkumar, and h. Freitas, "Plant growth promoting rhizobacteria and endophytes accelerate phytoremediation of metalliferous soils," Biotechnology Advances, vol. 29, pp. 248-258, 2011.

[37] R. Andreazza, B. Okeke, S. Pieniz, and F. Camargo, "Characterization of copper-resistant rhizosphere bacteria from Avena sativa and Plantago lanceolata for copper bioreduction and biosorption," Biological Trace Element Research, vol. 146, pp. 107-115, 2012.

[38] M. Rajkumar, S. Sandhya, M. Prasad, and H. Freitas, "Perspectives of plant-associated microbes in heavy metalphytoremediation," Biotechnology Advances, vol. 30, pp. 1562-1574, 2012.

[39] S. Chatterjee, G. Sau, and S. Mukherjee, "Plant growth promotion by a exavalent chromium reducing bacterial strain, Cellulosimicrobium cellulans KUCr3," World Journal of Microbiology \& Biotechnology, vol. 25, pp. 1829-1836, 2009.

[40] V. Ganesan, "Rhizoremediation of cadmium soil using a cadmium-resistant plant growth-promoting rhizopseudomonad," Current Microbiology, vol. 56, pp. 403-407, 2008.

[41] J. Park, N. Bolan, M. Megharaj, and R. Naidu, "Isolation of phosphate solubilizing bacteria and their potential for lead immobilization in soil," Journal of Hazardous Materials, vol. 185, pp. 829-836, 2011.
[42] Y. Ma, M. Rajkumar, J. Vicente, and H. Freitas, "Inoculation of Ni-resistant plant growth promoting bacterium Psychrobacter sp. strain SRS8 for the improvement of nickel phytoextraction by energy crops," International Journal of Phytoremediation, vol. 13, pp 126-139, 2010.

[43] M. Rajkumar, Y. Ma, and H. Freitas, "Improvement of hytostabilization by inoculation of Ni resistant Bacillus megaterium SR28C," Journal of Environmental Management, vol. 128, pp. 973-980, 2013.

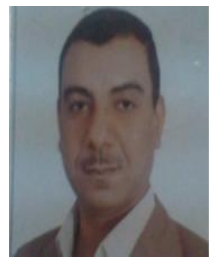

H. M. Mohamed is an assistant professor in Soils and Water Department at Faculty of Agriculture, Assiut University, Egypt. His field of interest is soil microbiology, biofirtlizers technology, environmental soil biology.

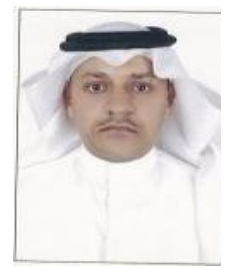

Y. Almaroai is an associate professor in the Department of Biology, College of Sciences, Umm Al-Qura University, Kingdom of Saudi Arabia. His research interests are related to biology in the environment heavy metal wastewater treatment and phytoremedation. 